\title{
Morphological traits and yield in common bean
}

\section{Características morfológicas e produtividade do feijão-comum}

\author{
Cleber Morais GUIMARÃES ${ }^{1}$; Luís Fernando STONE²; Leonardo Cunha MELO³; Mônica Ferreira de MELO; \\ José Ângelo Vitorino da SILVA5; Raquel Silva SOUSA ${ }^{6}$; Rogério Pereira de MORAES ${ }^{7}$
}

${ }^{1}$ Engenheiro-Agrônomo, Doutor, Embrapa Arroz e Feijão, e-mail: cleber.guimaraes@embrapa.br

${ }^{2}$ Autor para correspondência, Engenheiro-Agrônomo, Doutor, Embrapa Arroz e Feijão, GO 462, km 12, Santo Antônio de Goiás/GO- CEP 75375-000, e-mail: luis.stone@embrapa.br

${ }^{3}$ Engenheiro-Agrônomo, Doutor, Embrapa Arroz e Feijão, e-mail: leonardo.melo@embrapa.br

${ }^{4}$ Engenheira-Agrônoma, B.S., Instituto Federal Goiano, Campus Ceres, e-mail: monicafmelo2012@hotmail.com

${ }^{5}$ Engenheiro-Agrônomo, B.S., Centro Universitário Uni-Anhanguera, e-mail: joseangeloja@hotmail.com

${ }^{6}$ Engenheira-Agrônoma, B.S., Centro Universitário Uni-Anhanguera, e-mail: raquelagro21@gmail.com

${ }^{7}$ Biólogo, B.S., Centro Universitário Uni-Anhanguera, e-mail: rogepere841@gmail.com

Recebido em: 04-08-2020; Aceito em: 28-12-2020

\begin{abstract}
It is necessary to explore the relationship between yield-related traits to define the appropriate selection procedures to improve bean yield. The relationships between yield and its components have been extensively investigated by common bean breeding programs. However, less attention has been given to morphological and physiological traits. This study evaluates the effects of morphological traits of bean plants on their yield. Forty-one carioca genotypes were evaluated in a randomized block design with three replicates. The abscission of flowers, flower buds, and newly formed pods was monitored and specific leaf mass, leaflet area, average length and thickness of racemes and peduncles, 100-grain weight, number of pods per plant, and yield were determined. Yield responded negatively to increases in raceme and peduncle length and number of pods per plant and positively to increases in peduncle thickness and grain weight. Genotypes differed regarding yield and grain weight and were divided into two groups by the Scott-Knott's test considering yield. The most productive group showed increased abscission of flowers and newly formed pods, decreased number of pods, and increased grain weight. The most productive genotypes were those that remobilized photoassimilates more easily for having shorter racemes and peduncles, thicker peduncles, and decreased expenditure of structural carbohydrates with malformed pods and other structures required for conditioning grains in the plant, compensating with greater grain weight.
\end{abstract}

Additional keywords: abscission of flowers and pods; leaf area; raceme and peduncle length; specific leaf mass; Phaseolus vulgaris $L$.

\begin{abstract}
Resumo
É necessário explorar a relação entre produtividade e características relacionadas, para definir os procedimentos de seleção adequados para melhorar a produtividade do feijoeiro. As relações da produtividade com seus componentes produtivos têm sido amplamente investigadas por programas de melhoramento de feijão-comum, contudo menor atenção tem sido dada às características morfológicas e fisiológicas. O trabalho objetivou avaliar os efeitos de características morfológicas das plantas de feijoeiro sobre sua produtividade. Foram avaliados 41 genótipos do tipo carioca, no delineamento experimental de blocos casualizados, com três repetições. Monitorou-se a abscisão de flores, de botões florais e de vagens recém-formadas e determinou-se a massa foliar específica, área foliar dos folíolos, comprimento e espessura média dos racemos e pedúnculos, massa de 100 grãos, número de vagens por planta e produtividade. A produtividade respondeu negativamente ao aumento no comprimento dos racemos e dos pedúnculos e ao número de vagens por planta, e positivamente ao aumento na espessura dos pedúnculos e massa dos grãos. Os genótipos diferiram quanto à produtividade e massa dos grãos e foram divididos em dois grupos pelo teste de Scott-Knott, considerando-se a produtividade. O grupo mais produtivo apresentou maior abscisão de flores e de vagens recém-formadas, menor número de vagens e maior massa de grãos. Os genótipos mais produtivos são aqueles que remobilizam fotoassimilados mais facilmente por apresentarem racemos e pedúnculos mais curtos, pedúnculos mais espessos e menor gasto de carboidratos estruturais com vagens malformadas e outras estruturas demandadas para 0 acondicionamento dos grãos na planta, compensando com maior massa dos grãos.
\end{abstract}

Palavras-chave adicionais: abscisão de flores e vagens; área foliar; comprimento de racemo e pedúnculo; massa foliar específica; Phaseolus vulgaris L. 


\section{Introduction}

Increasing bean yield is important for millions of people in developing and developed countries worldwide. Understanding the production physiology of this crop is one of the most important aspects to achieve this objective. Higher yields are only possible when various physiological processes or yield components are appropriately balanced (Fageria \& Santos, 2008).

Yield improvement is an objective of most crop improvement programs. As in other crops, the grain yield of the common bean is a complex characteristic, consisting of many morphological and physiological traits (Negahi et al., 2014). It has a quantitative nature, being ruled by several major and minor genes, and being affected by variations in environmental factors, hampering direct selection for yield, which may not be successful. Direct selection of another simply inherited trait strongly correlated with yield facilitates selection procedures and lead to the desired progress in breeding programs. Therefore, it is necessary to explore the relationship between yield-related traits to define the appropriate selection procedures to improve bean yield (Al-Ballat \& Al-Araby, 2019), which requires good knowledge of the associations of different traits with yield and among traits (Negahi et al., 2014).

Yield traits (number of pods per plant, number of grains per plant, number of grains per pod, 100-grain weight, and grain yield) have been extensively investigated by common bean breeding programs (Ribeiro et al., 2018). However less attention has been given to morphological and physiological traits.

Checa \& Blair (2012) found that traits such as raceme length, number of pods per raceme, and pod length are of great importance to improve common beans for high yield. Okii et al. (2014) and Ejara et al. (2017) recommended to consider the number of nodes on the main stem in improvement programs. According to White \& Izquierdo (1989), flowers with short peduncles, large cross section, and large leaves, close to storage sites, can increase bean yield by increasing the volume of photoassimilates produced and by reducing the flow resistance of assimilates to storage sites.

Therefore, this study evaluates the effects of morphological traits of the bean plant on its yield.

\section{Material and methods}

The experiment was conducted from July to October 2018 in the municipality of Santo Antônio de Goiás, Goiás state, Brazil (16 $36^{\circ} 13.23^{\prime \prime} \mathrm{S}$ and $49^{\circ} 16^{\prime}$ 54.73 " W). The climate, according to the Köppen's classification system, is Aw, savanna tropical, megathermal.

The randomized block experimental design was used, with three replicates. In the plots, 41 genotypes of the Embrapa common bean breeding pro- gram, adapted to the climate and soil conditions of the study site, were evaluated. Sowing was conducted on $7 / 4 / 2018$ in plots with three rows 3-m long, spaced 0.50 $\mathrm{m}$ apart. The usable area consisted of a 2-m long row. The soil of the experimental area is an Acric Red Latosol whose chemical analysis showed the following results: $\mathrm{pH}\left(\mathrm{H}_{2} \mathrm{O}\right)=5.5 ; \mathrm{Ca}=18.6 \mathrm{mmol}_{\mathrm{c}} \mathrm{dm}^{-3} ; \mathrm{Mg}=$ $=10.4 \mathrm{mmol}_{\mathrm{c}} \mathrm{dm}^{-3} ; \mathrm{Al}=1 \mathrm{mmol}_{\mathrm{c}} \mathrm{dm}^{-3} ; \mathrm{P}=13.4 \mathrm{mg} \mathrm{dm}^{-3}$; $\mathrm{K}=48 \mathrm{mg} \mathrm{dm}^{-3} ; \mathrm{Cu}=1.0 \mathrm{mg} \mathrm{dm}^{-3}, \mathrm{Zn}=11.8 \mathrm{mg} \mathrm{dm}^{-3}$, $\mathrm{Fe}=27.8 \mathrm{mg} \mathrm{dm}^{-3}, \mathrm{Mn}=6.8 \mathrm{mg} \mathrm{dm}^{-3}$. Fertilization was performed with application of $250 \mathrm{~kg} \mathrm{ha}^{-1}$ of monoammonium phosphate at sowing and topdressing of $80 \mathrm{~kg} \mathrm{ha}^{-1}$ of $\mathrm{N}$ in the $\mathrm{V} 4$ stage (third trifoliate leaf open). The other agronomic managements were those recommended for the crop (Carneiro et al., 2015).

The abscission of flowers, flower buds, pods at the beginning of development, and leaf area and mass were monitored. To quantify the abscission of flowers, flower buds, and pods at the beginning of development, 82 collecting nets of $1 \times 0.50 \mathrm{~m}$ were made with plastic net, string, and iron bar. The collection nets were distributed on 08/09/2018, R5 development stage (pre-flowering), between the rows with plants evenly distributed. The earliest genotypes, $54 \%$ of the total, showed the beginning of $R 6$ (flowering) at 32 DAE (days after emergence) and the remainder up to 36 DAE. Collections were conducted every two days from $08 / 10 / 2018$ until the end of flowering of all plants in the experiment, on 09/14/2018. In order to determine the specific leaf mass (leaf dry matter/leaf area) used to infer carbohydrate accumulation in the leaf, five trifoliates were collected per plot weekly. Trifoliates of the apex of plants that were undamaged and in full development were selected. Trifoliate leaf areas were determined with the aid of the leaf area meter LI 3100. After drying in a forced air circulation oven at $80{ }^{\circ} \mathrm{C}$ for 48 hours, trifoliates were weighed on an analytical balance to determine dry matter.

At the maturation stage, five plants were collected to determine the average length and thickness of racemes and peduncles and the number of pods per plant. In the evaluation of average thickness of racemes and peduncles, the individual average of the largest and the shortest length of the cross section of the center of these plant components was considered. Grain yield and 100-grain weight were also evaluated. The 100-grain weight was determined by the average weight of two samples of 100 grains per plot. Grain yield was determined from the grain mass of the usable area corrected to $13 \%$ moisture and expressed in $\mathrm{kg} \mathrm{ha}^{-1}$.

Yield and 100-grain weight data were submitted to analysis of variance by $F$ test using the GLM procedure of the SAS statistical program (SAS Institute, 1999). Means were compared by Scott-Knott's test at 0.05 probability level. Regression analyzes were also performed between the variables evaluated. 


\section{Results and discussion}

The number of grains per raceme increased linearly with raceme length (Figure $1 \mathrm{~A}$ ), which explained $11 \%$ of the variability of that number. The greater number of pods in the longest racemes increased the number of grains. Checa \& Blair (2012) also found significant and positive correlation between raceme length and number of pods per raceme of common bean. Yamaguchi et al. (2014) found that soybean cultivars with longer racemes had a greater number of pods per raceme. Common bean flowers originate from raceme nodes. Therefore, the longer the raceme length, the greater the number of nodes and consequently the greater the number of flowers, pods, and grains per raceme.

Increase in the number of grains in the raceme and raceme length decreased 100-grain weight (Figure 1B) probably due to decreased photoassimilate availability associated with increased resistance of its flow, which is caused by the longer phloem path of longer racemes. Raceme length explained $16 \%$ of the variability of 100-grain weight in the raceme. White \& Izquierdo (1989) postulated that long racemes with smaller phloem section increased the flow resistance of photoassimilates to the storage sites, decreasing their availability for accumulation in the grains.

Grain mass decrease in each raceme caused by its increased length decreased 100-grain weight in the plant as a whole (Figure 2A), probably due to the greater number of grains per plant caused by the increased number of pods per plant. Checa \& Blair (2012) also observed that the number of pods per plant was positively correlated with the number of pods per raceme. Mismatch was observed between the increase of sites of carbohydrate storage and carbohydrate availability for its fulfillment. As the number of pods per plant and grains per pod increased, grain mass decreased due to limited carbohydrate availability to form the grains present in greater numbers in the plants.
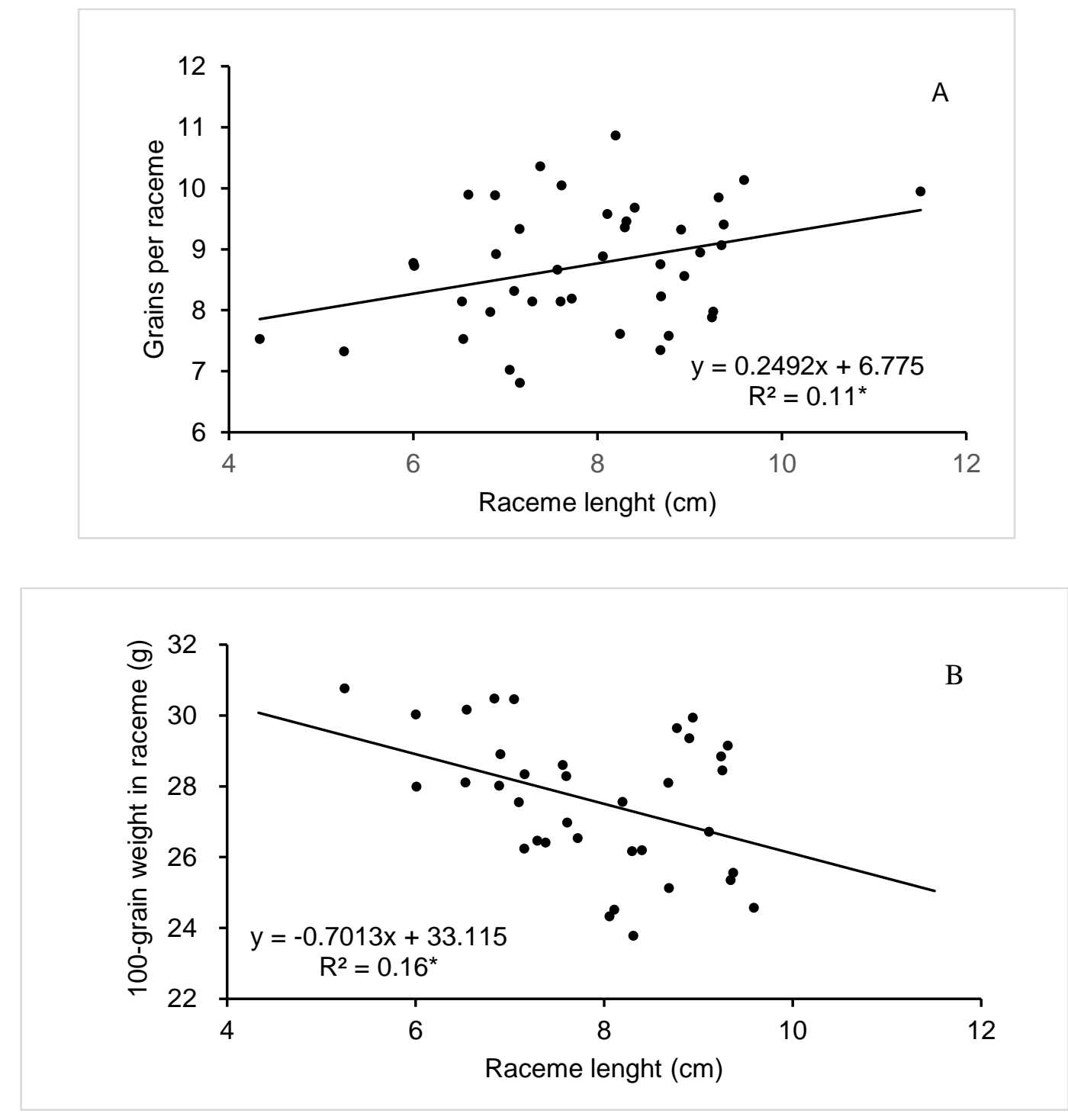

Figure 1 - Effect of raceme length on the number of grains per raceme $(A)$ and on 100-grain weight in raceme (B) of 41 common bean genotypes. 
Rana et al. (2015) observed negative correlation between 100-grain weight of beans and number of pods per plant and grains per pod. Okii et al. (2014) observed that the 100-grain weight of beans was negatively correlated with the number of locules formed per pod, while Loko et al. (2018) observed negative correlation of 100-grain weight with the number of grains per pod.

Yield increased linearly as raceme length decreased, explaining $23 \%$ of the yield variation of bean genotypes (Figure 2B). Each decrease of one unit in raceme length resulted in a yield increase of $260 \mathrm{~kg} \mathrm{ha}^{-1}$. In contrast to this result, Checa \& Blair (2012) observed positive correlation between yield and raceme length, probably for being a study of recombinant lines that had a creole and climbing variety, adapted to high altitude, that has a shoot architecture atypical to that of the commercial bean genotypes evaluated in the present study, which prioritized the remobilization of photoassimilates for grain production.
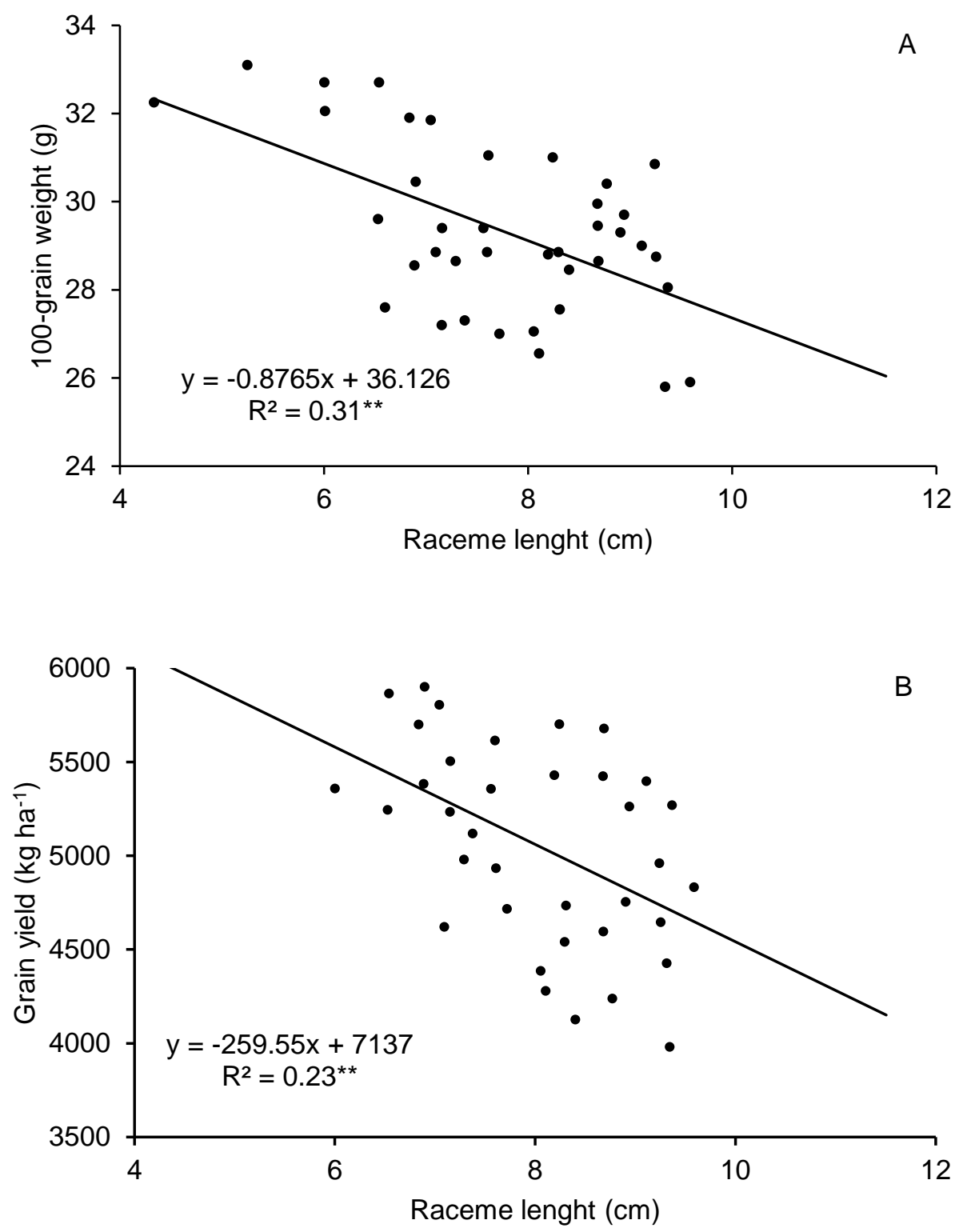

Figure 2 - Effect of raceme length on grain weight (A) and on grain yield (B) of 41 common bean genotypes.

In the present study, yield increase along with raceme length decrease can be explained by its negative relationship with the number of pods per plant (Figure 3) and positive relationship with grain mass (Figure 4), considering the 41 genotypes evaluated. Önder et al. (2013) and Ejara et al. (2017) also observed negative relationship between yield and number of pods per plant and postulated that this may be caused by negative indirect effects of this trait on the number of grains per pod and per plant and on 100-grain weight. Depending on environmental conditions and genotypes, some yield components may increase and others may 
decrease. This effect is attributed to compensatory growth, as the distribution of yield-limiting resources is affected by genetic and environmental factors. The main implication of this process is that the increase of one component may not result in yield increases (White \& Izquierdo, 1989), as verified with the number of pods per plant.

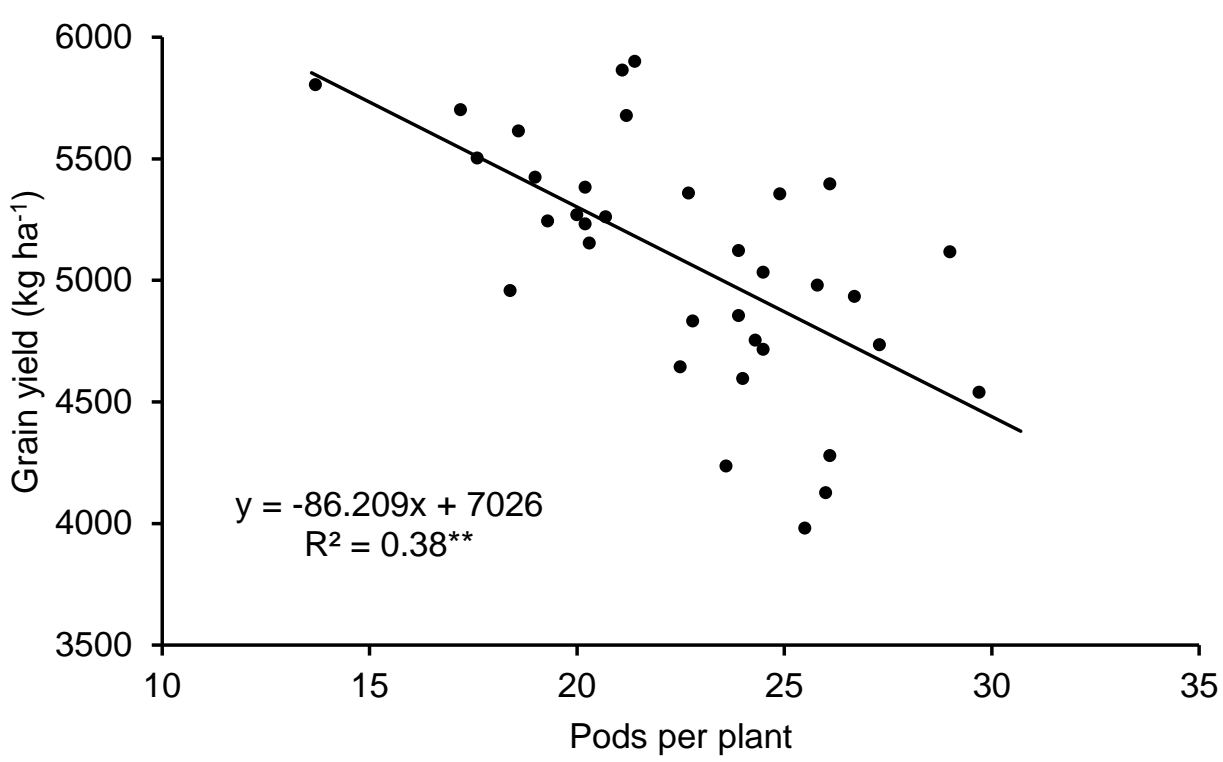

Figure 3 - Effect of number of pods per plant on grain yield of 41 common bean genotypes.

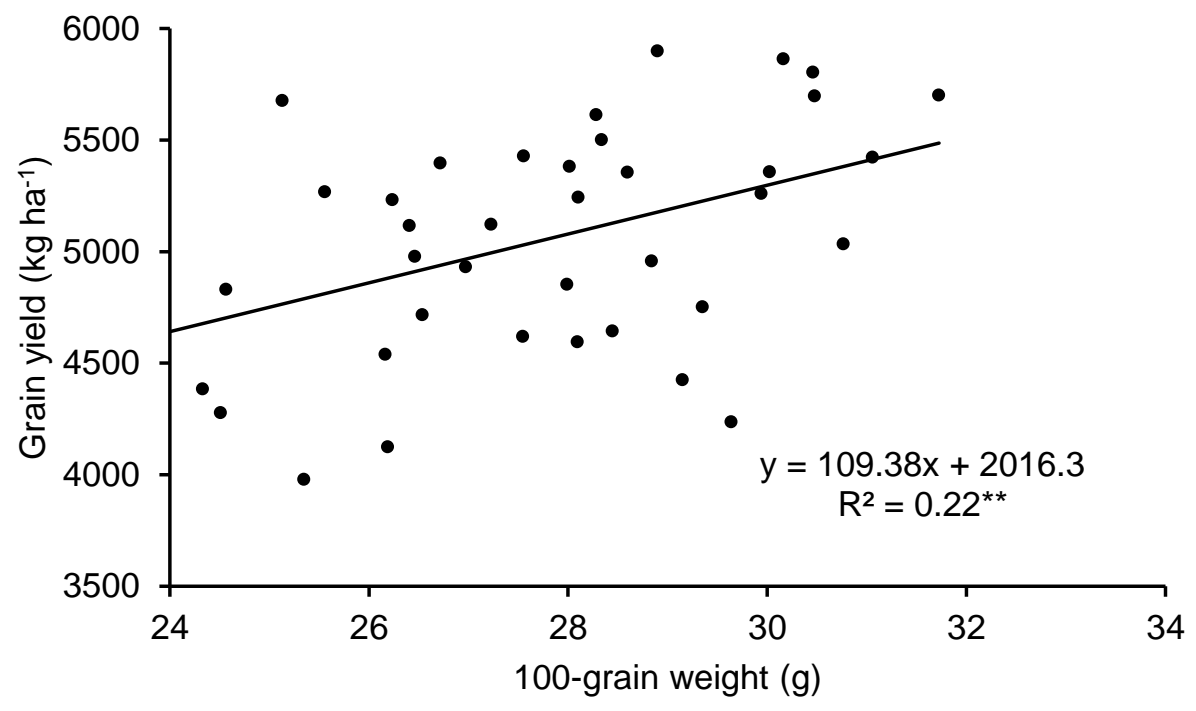

Figure 4 - Effect of 100-grain weight on grain yield of 41 common bean genotypes.

Fageria \& Santos (2008), Negahi et al. (2014), Ejara et al. (2017), and Ribeiro et al. (2018) observed positive correlation between 100-grain weight and bean yield. The latter authors found no correlation between yield and the number of pods and grains per plant. On the other hand, Fageria \& Santos (2008), Negahi et al. (2014), and Al-Ballat \& Al-Araby (2019) observed positive correlation between yield and number of pods per plant. Negahi et al. (2014) also observed a positive correlation between yield and number of grains per plant.
Peduncle length also affected grain formation. Shorter peduncles resulted in grains with greater mass accumulation, being heavier. The variability of peduncle length explained $16 \%$ of variability in grain mass (Figure $5 A)$. Each decrease of one unit in peduncle length increased 100-grain weight by $5.9 \mathrm{~g}$. Yield was also influenced by peduncle length, increasing linearly with its decrease (Figure 5B). Peduncle length explained $13 \%$ of variation in the yield of the common bean and each unit of reduction in its length resulted in a yield increase of $1210 \mathrm{~kg} \mathrm{ha}^{-1}$. 

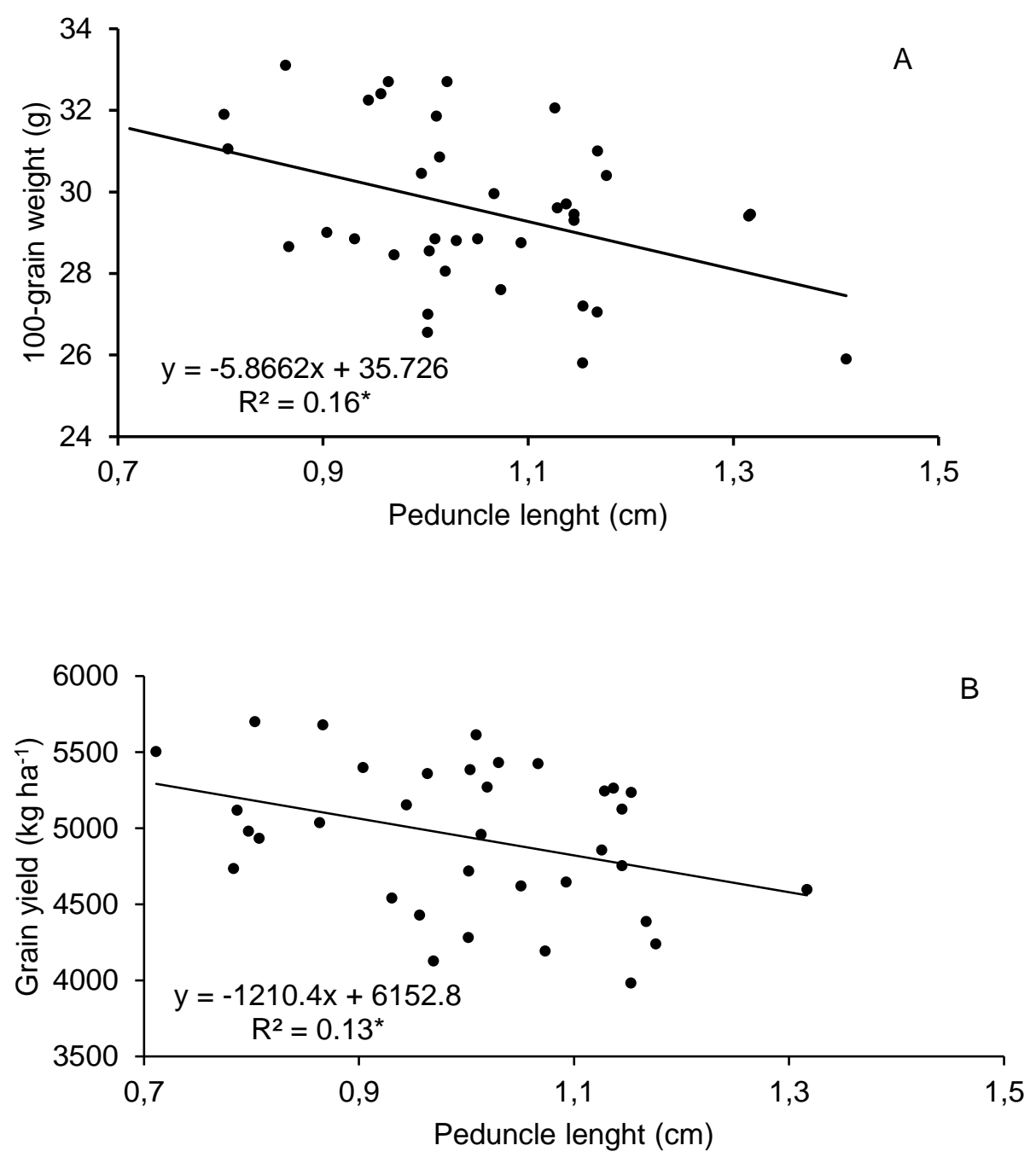

Figure 5 - Effect of peduncle length on 100-grain weight (A) and on grain yield (B) of common bean.

Significant effect of raceme thickness on 100- variability of yield in the genotypes evaluated in the grain weight and yield of beans was not observed. However, yield responded positively to peduncle thickness (Figure 6 ). Its variability explained $15 \%$ of the experiment. Each unit of variation in peduncle thickness resulted in an average increase of $390 \mathrm{~kg} \mathrm{ha}^{-1}$ in the grain yield of bean genotypes.

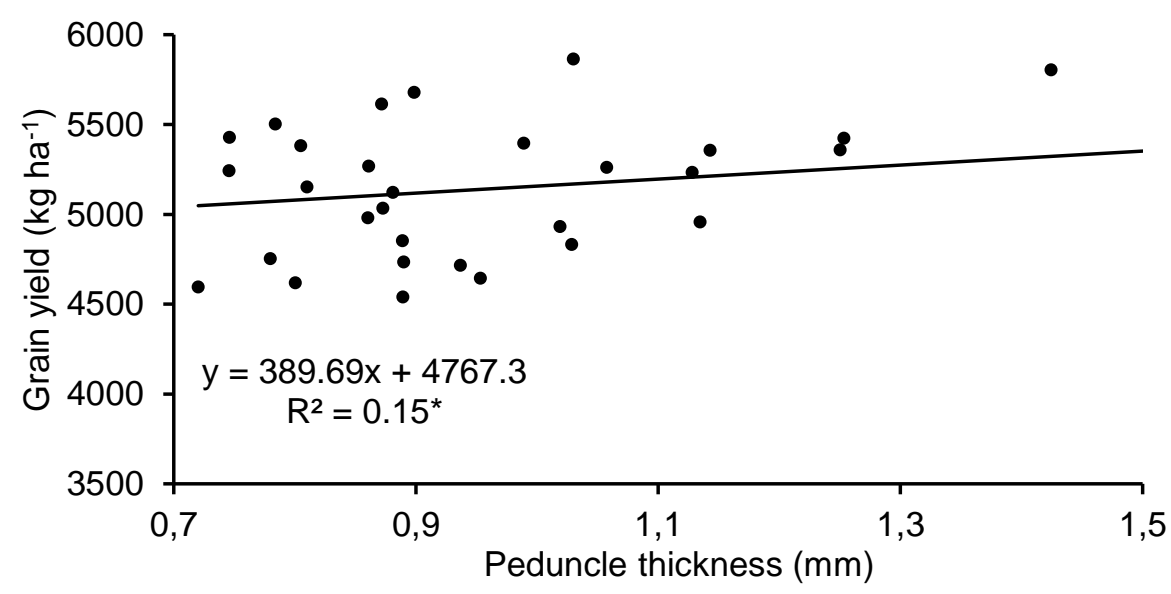

Figure 6 - Effect of peduncle thickness on grain yield of 41 common bean genotypes. 
According to White \& Izquierdo (1989), flowers with short peduncles, large cross section, and large leaves, close to storage sites, can increase yield by increasing the volume of photoassimilates produced and by reducing the flow resistance of assimilates to storage sites.

Phloem translocation is ruled by a pressure gradient generated osmotically between source and drain, which is affected both by the cross section of the sieved elements and by the distance to be covered (Taiz \& Zeiger, 2010). The length of racemes and peduncles determine the distance of the path to be crossed by photoassimilates towards the drain, and the diameter of the translocation path in the phloem can be inferred by the thickness of racemes and peduncles.

Response of yield to carbohydrate accumulation in the leaves, inferred by the specific leaf mass evaluated in the early hours of the morning, was not observed. Response of yield to trifoliate area was also not observed possibly due to the large leaf areas of the genotypes evaluated. Yield increases with increasing leaf area up to a limit, above which there is no further increase. Mutual shading of leaves can decrease their photosynthetic efficiency. In addition, the respiration rate increases almost proportionally to the increase in leaf area as it is not affected by mutual shading (Fageria \& Santos, 2008).

The genotypes evaluated differed significantly regarding yield and 100-grain weight (Table 1). Considering yield, genotypes were divided into two groups by Scott-Knott's test. The first group was formed by 22 genotypes that produced between $5756 \mathrm{~kg} \mathrm{ha}^{-1}$ and $4853 \mathrm{~kg} \mathrm{ha}^{-1}$ and the second group by 19 genotypes that produced between $4782 \mathrm{~kg} \mathrm{ha}^{-1}$ and $3848 \mathrm{~kg} \mathrm{ha}^{-1}$.

Table 1 - Grain yield and 100-grain weight of common bean genotypes.

\begin{tabular}{|c|c|c|}
\hline Genotype & Grain yield (kg ha $\left.{ }^{-1}\right)$ & 100-grain weight $(\mathrm{g})$ \\
\hline Pérola & $5756 a$ & $30.7 b$ \\
\hline CNFC 17271 & $5611 a$ & $28.5 c$ \\
\hline CNFC 17275 & $5603 a$ & $31.2 b$ \\
\hline CNFC 17304 & $5535 a$ & $33.1 \mathrm{a}$ \\
\hline CNFC 17305 & $5476 a$ & $32.5 a$ \\
\hline CNFC 17170 & $5327 a$ & $29.2 c$ \\
\hline CNFC 17303 & $5327 a$ & $31.3 b$ \\
\hline CNFC 17259 & $5299 a$ & $29.3 c$ \\
\hline CNFC 17273 & $5231 a$ & $31.9 a$ \\
\hline CNFC 17260 & $5191 \mathrm{a}$ & $29.4 c$ \\
\hline CNFC 17182 & $5186 a$ & $27.3 d$ \\
\hline CNFC 17264 & $5170 \mathrm{a}$ & $30.1 \mathrm{~b}$ \\
\hline IPR Campos Gerais & $5066 a$ & $27.3 d$ \\
\hline CNFC 17172 & $5062 a$ & $28.8 \mathrm{c}$ \\
\hline CNFC 17302 & $5058 a$ & $32.5 a$ \\
\hline ANFC 09 & $5054 a$ & $29.9 b$ \\
\hline CNFC 17330 & $5023 a$ & $29.7 c$ \\
\hline CNFC 17236 & $5005 a$ & $28.8 \mathrm{c}$ \\
\hline BRS Estilo & $4982 a$ & $28.6 c$ \\
\hline CNFC 17265 & $4902 a$ & $28.1 \mathrm{c}$ \\
\hline CNFC 17301 & $4874 a$ & $32.4 a$ \\
\hline CNFC 17318 & $4853 a$ & $32.6 \mathrm{a}$ \\
\hline CNFC 17411 & $4782 b$ & $28.6 \mathrm{c}$ \\
\hline CNFC 17328 & $4769 b$ & $28.8 \mathrm{c}$ \\
\hline CNFC 17347 & $4764 b$ & $30.2 b$ \\
\hline CNFC 17278 & $4756 b$ & $27.8 d$ \\
\hline CNFC 17309 & $4636 b$ & $30.9 b$ \\
\hline CNFC 17268 & $4616 b$ & $29.4 c$ \\
\hline CNFC 17180 & $4606 b$ & $32.4 \mathrm{a}$ \\
\hline CNFC 17324 & $4546 b$ & $28.0 d$ \\
\hline CNFC 17270 & $4492 b$ & $30.0 \mathrm{~b}$ \\
\hline CNFC 17310 & $4442 b$ & $27.4 d$ \\
\hline CNFC 17308 & $4392 b$ & $26.5 e$ \\
\hline CNFC 17238 & $4370 b$ & $29.0 \mathrm{c}$ \\
\hline CNFC 17279 & $4353 b$ & $29.3 c$ \\
\hline CNFC 17314 & $4282 b$ & $27.9 d$ \\
\hline BRS FC402 & $4183 b$ & $25.8 \mathrm{e}$ \\
\hline CNFC 17335 & $4140 \mathrm{~b}$ & $28.4 \mathrm{c}$ \\
\hline CNFC 17164 & $4099 b$ & $29.3 c$ \\
\hline CNFC 17257 & $4035 b$ & $30.6 b$ \\
\hline BRS Notável & $3848 b$ & $26.2 e$ \\
\hline
\end{tabular}

Means followed by the same letter in the column did not differ significantly at the level of $5 \%$ by the Scott-Knott's test. 
The averages of the accumulated abscission of flowers and new pods of the two groups that showed similar yields by Scott-Knott's test are shown in Figure 7. The most productive group presented the greatest accumulated abscission of flowers and newly formed pods throughout evaluation, 96 and 93, respectively (Figure 7A). The least productive group presented abscission of 75 flowers and 85 newly formed pods during the same period (Figure 7B). The data suggested that the most productive genotypes are those with the greatest abscission of these reproductive organs, resulting in a decreased number of pods per plant, which is supported by the negative response of yield to the increase in the number of pods per plant (Figure 3). On the other hand, it was observed that the most productive genotypes were those that presented better formed grains and with less expenditure of structural carbohydrates for the formation of pods and other structures required for conditioning grains in the plant, as observed in Figure 4. The group with the most productive genotypes presented a 100-grain weight of $30.1 \mathrm{~g}$, while the least productive group presented $28.6 \mathrm{~g}$.
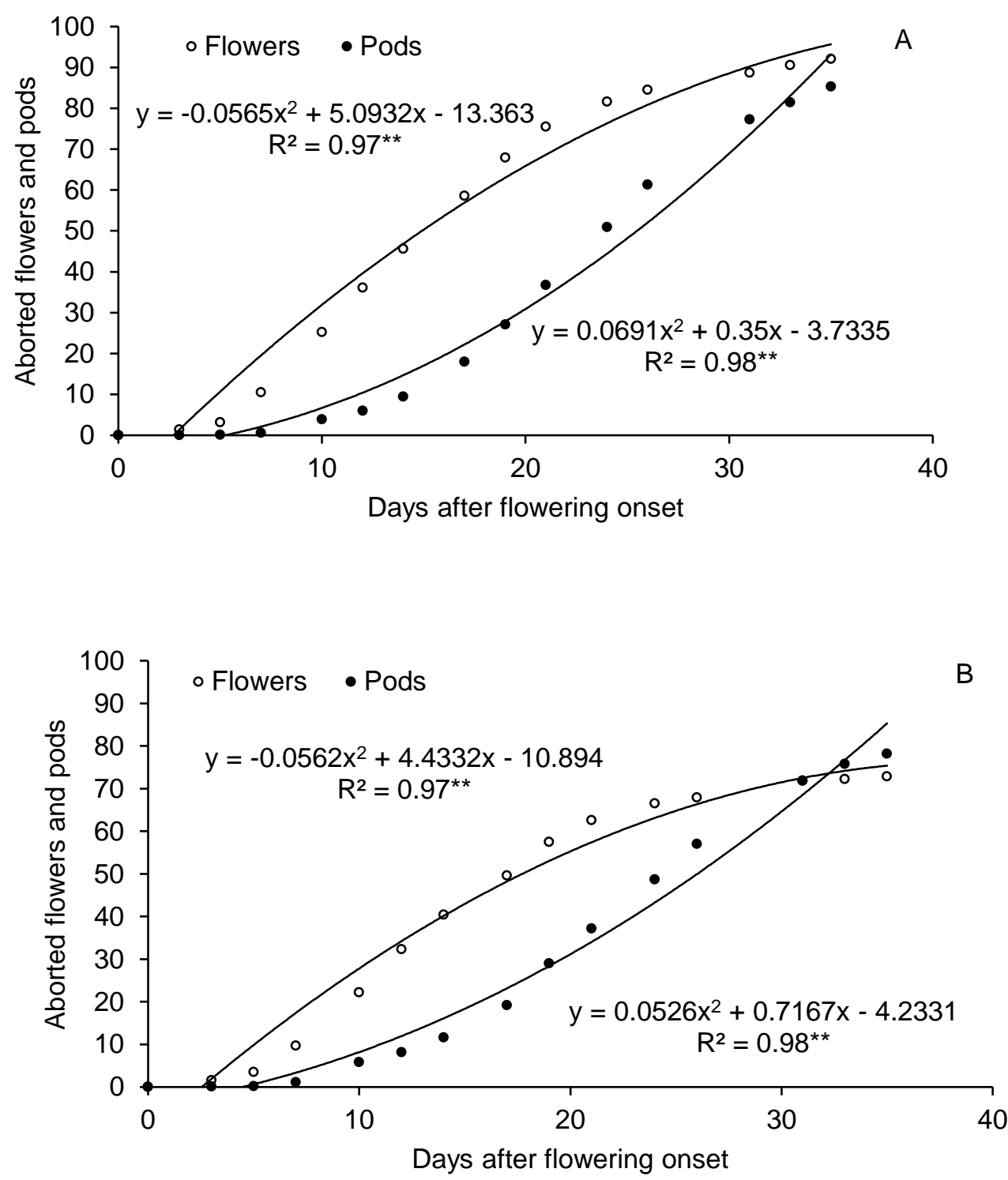

Figure 7 - Cumulative abscission of flowers and newly formed pods from the most productive $(A)$ and least productive $(B)$ groups according to the grouping test of means.

Carbohydrate supply by the source may not adequately supply pods during grain formation, as the carbohydrate content in the pod wall decreases intensely during this stage, suggesting that the remobilization of carbohydrates in the pod wall occurs without limitations, although it is not verified regarding its replacement from the temporary storage in the culms (Tanaka \& Fujita, 1979). Inadequate supply of carbohydrates establishes competitiveness in favor of other organs and older pods, causing the abscission of 
younger pods and poor formation of grains (White \& Izquierdo, 1989).

The negative effects of increasing the length of racemes and peduncles on grain yield and mass, caused by increasing the flow resistance of photoassimilates and by unnecessary expenditures of structural carbohydrates caused by the increase of malformed pods, suggest the introduction of these traits in the selection of common bean lines for high yield.

\section{Conclusions}

The most productive genotypes were those that remobilized photoassimilates more easily for having shorter racemes and peduncles, thicker peduncles, and decreased expenditure of structural carbohydrates with malformed pods and other structures required for conditioning grains in the plant, compensating with greater grain weight.

\section{References}

Al-Ballat IA, Al-Ballat AA (2019) Correlation and path coefficient analysis for seed yield and some of its traits in common bean (Phaseolus vulgaris L.). Egyptian Journal of Horticulture 46(1):41-51. doi: 10.21608/ejoh.2018.6481.1088

Carneiro JE, Paula Júnior TJ de, Borém A (2015) Feijão: do plantio à colheita. UFV. 384p.

Checa OE, Blair MW (2012) Inheritance of yield-related traits in climbing beans (Phaseolus vulgaris L.). Crop Science 52(5):1998-2013. doi: 10.2135/cropsci2011.07.0368

Ejara E, Mohammed W, Amsalu B (2017) Correlations and path coefficient analyses of yield and yield related traits in common bean accessions (Phaseolus vulgaris L.) at Abaya and Yabello, Southern Ethiopia. International Journal of Plant Breeding and Crop Science 4 (2):215-224.

Fageria NK, Santos AB (2008) Yield physiology of dry bean. Journal of Plant Nutrition 31(6):983-1004. doi: $10.1080 / 01904160802096815$

Loko LEY, Orobiyi A, Adjatin A, Akpo J, Toffa J, Djedatin G, Dansi A (2018) Morphological characterization of common bean (Phaseolus vulgaris L.) landraces of Central region of Benin Republic. Journal of Plant Breeding and Crop Science 10(11):304-318. doi: 10.5897/JPBCS2018.0766
Okii D, Tukamuhabwa P, Odong T, Namayanja A, Mukabaranga J, Paparu P, Gepts P (2014) Morphological diversity of tropical common bean germplasm. African Crop Science Journal 22(1):59-67.

Önder M, Kahraman A, Ceyhan E (2013) Correlation and path analysis for yield and yield components in common bean genotypes (Phaseolus vulgaris L.). Ratarstvo i Povrtarstvo 50(2):14-19. doi: 10.5937/ratpov50-3958

Negahi A., Bihamta MR, Negahi Z, Alidoust M (2014) Evaluation of genetic variation of some agronomical and morphological traits in Iranian and exotic common bean (Phaseolus vulgaris L.). Agricultural Communications 2(3):22-26.

Rana JC, Sharma TR, Tyagi RK, Chahota RK, Gautam NK, Singh M, Sharma PN, Ojha SN (2015) Characterisation of 4274 accessions of common bean (Phaseolus vulgaris L.) germplasm conserved in the Indian gene bank for phenological, morphological and agricultural $\begin{array}{llll} & \text { traits. Euphytica } 205 & \text { (2):441-457. }\end{array}$ 10.1007/s10681-015-1406-3

Ribeiro ND, Santos GG, Maziero SM, Steckling SM (2018) Phenological, plant architecture, and grain yield traits on common bean lines selection. Revista Caatinga 31(3):657-666. doi: doi.org/10.1590/198321252018v31n314rc

SAS Institute (1999) Procedure guide for personal computers. SAS Institute. 552p.

Taiz L, Zeiger E (2010) Plant Physiology. Sinauer Associates. 782p.

Tanaka A, Fujita K (1979) Growth, photosynthesis, and yield components in relation to grain yield of the field bean. Journal of the Faculty of Agriculture Hokkaido University 59(2):145-238.

White W, Izquierdo J (1989) Dry bean: physiology of yield potential and stress tolerance. FAO Regional Office for Latin America and the Caribbean. 81p.

Yamaguchi N, Sayama T, Sasama H, Yamazaki H, Miyoshi T, Tanaka Y, Ishimoto M (2014) Mapping of quantitative trait loci associated with terminal raceme length in soybean. Crop Science 54(6):2461-2468. doi: 10.2135/cropsci2014.03.0226 